\title{
MONITORING NESTING SITES OF LESSER FLORICANS (SYPHEOTIDES INDICA) IN AND AROUND BLACKBUCK NATIONAL PARK, GUJARAT
}

\author{
Indra R. Gadhvi \\ Zoology Department, Sir P.P. Institute of Science (Bhavnagar University), Waghavadi Road, Bhavnagar, Gujarat 364002, India \\ Email:indragadhvi@rediffmail.com
}

\begin{abstract}
The grasslands of Blackbuck National Park, Gujarat provide a major breeding ground for the Lesser Florican (Sypheotides indica). The study to identify potential nesting area of Lesser Florican and disturbance factors for the conservation and management of the species was conducted over 150 days from June to October 2001. Thirty-eight male and 16 female floricans were sighted and a total of five nests were recorded during the study with an average clutch size of 4-5 eggs. Local people of the surrounding area were contacted and made aware about the present status of the species.
\end{abstract}

\section{Keywords}

Bhal, Blackbuck National Park, grassland, Gujarat, Lesser Florican, monitoring, nesting sites, Sypheotides indica

\section{Introduction}

Six species of bustards (Otididae) occur in the Indian subcontinent. Great Indian Bustard Ardeotis nigriceps (Vigors, 1831), the Lesser Florican Sypheotides indica (Miller, 1782) and the Bengal Florican Houbaropsis bengalensis (Gmelin,1789) breed in India, while the Great Bustard Otis tarda (Linne'), the Little Bustard Tetrax tetrax (Linne') and the Houbara Chlamydotis undulata (Jacquin) are occasional or common winter migrants (Grimmett et al., 1998). The Lesser Florican and the Great Indian Bustard are endemic to the Indian subcontinent, while a sub species of the Bengal Florican is found in Cambodia, and Vietnam as well (Osborne et al., 1984). All the three resident bustards of India are Critically Endangered (Collar \& Andrew, 1994).

The Lesser Florican is amongst the smallest bustards of the world. It is the smallest Indian member of Family Otididae and endemic to the Indian grassland. The Lesser Florican is protected under schedule I of the Wildlife (Protection) Act 1972 and its hunting, trapping or shooting is prohibited in India. In Saurashtra and Kutch the Lesser Florican is called Tilor. In Bhal area of Bhavnagar District, it is also called Dumbharo. The most recent surveys in 1999 (Sankaran, 2000), have estimated a population of 3530 birds and it is considered as the most endangered bustard in India as well as in the world (del Hoyo et al., 1996), as it's breeding habitat is under severe threat from land use changes. According to world lists of threatened birds, by BirdLife International, the Lesser Florcian is enlisted as "Critically Endangered". Its population is judged to have plummeted by $80 \%$ in seven years form 1982 (4374) to 1989 (750) (Sankaran, 1991, 1994, 1995, 2000; Sankaran et al., 1992). Its breeding success depends on the quantum and distribution of monsoon, which is highly uncertain across all its breeding range, and nest disturbance (Sankaran, 1994).

Blackbuck National Park is subtropical grassland with shrubland situated near the western shore of the Gulf of Khambhat in the Bhal region. The prime goals of this protected area are to conserve largest surviving herds of Blackbuck (Antelope cervicapra), Indian Grey Wolf(Canis lupus) and the Lesser Florican. The Blackbuck National Park and the surrounding area was private grazing land of the Maharaja of Bhavnagar and supported remarkable population of Lesser Florican as early as 1950 s. The Forest Department has been carrying out census of male Lesser Florican for the past 8 to 9 years (Singh, 2001). In the past five years grassland management practices have been able to attract about 30 to 45 Lesser Floricans during monsoon (Rana, pers. comm.). This number is the highest density of breeding Lesser Florican recorded so far in any grasslands of India (Sankaran, 1996). Though the monitoring of number of Lesser Florican is reliably done by the Forest Department there has not been any systematic approach made towards evaluating the contribution of such a large congregation of the birds to its population.

The information available on the nesting (Rana, pers. comm.) suggests that more nests are found outside the protected area 


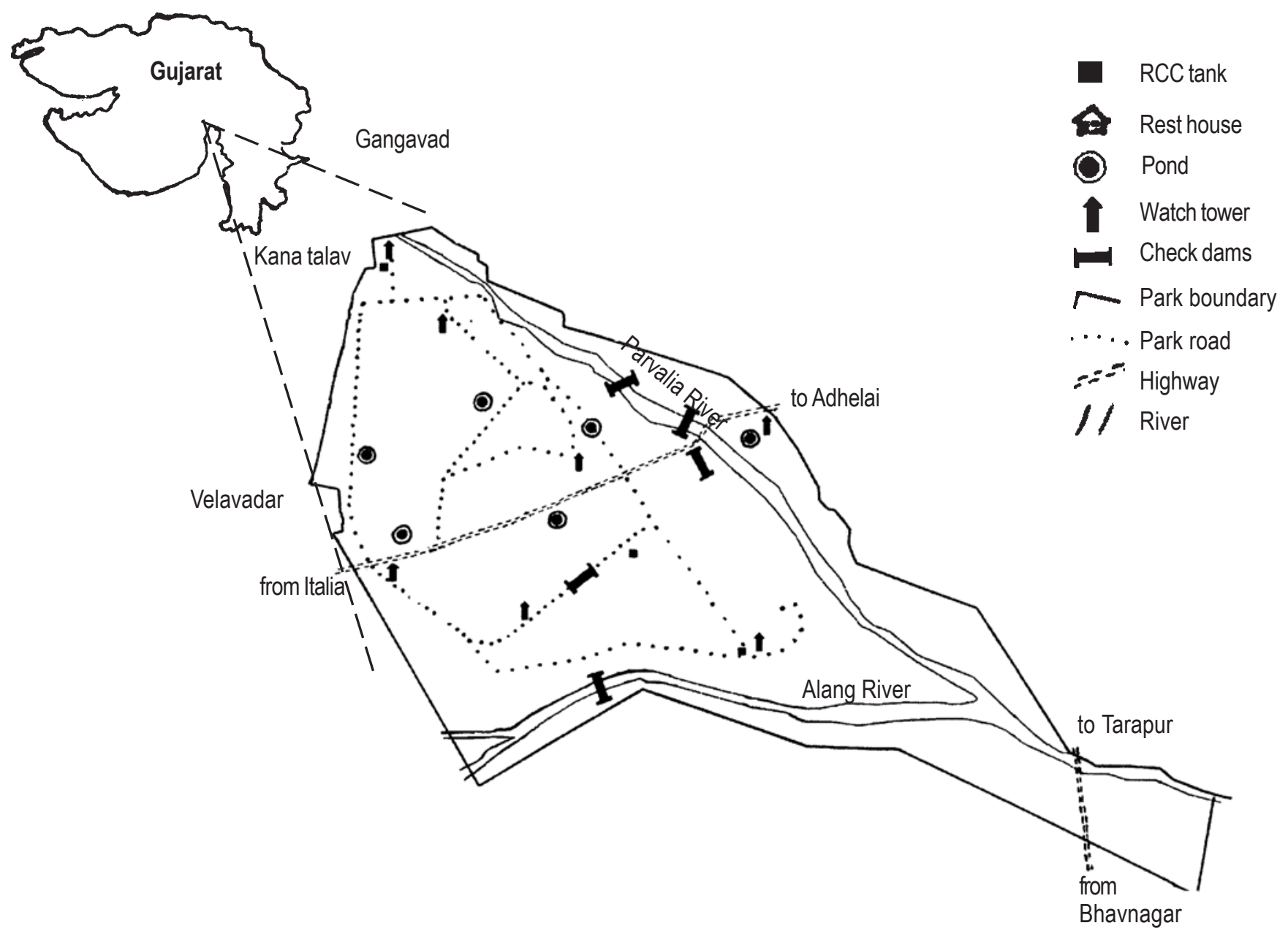

Figure 1. Study site

distributed in an approximately $10 \mathrm{~km}$ radius from the Velavadar National Park. These nests are found in revenue grazing land, wasteland as well as in the sorghum fields. These nests are at a greater risk of being destroyed. Constant movement of people in the fields and cattle in the revenue grazing land and wasteland coincides with the nesting of Lesser Florican. The nests have been destroyed by the farmers unknowingly and due to cattle trampling (pers. obs.). An attempt was made to locate and monitor these nests to collect baseline information on nesting activities of Lesser Florican and to identify their nesting areas for protection in future.

\section{Study site}

Blackbuck National Park is located at latitude $21^{\circ} 56^{\prime} \mathrm{N}$ and longitude $72^{\circ} 10^{\prime} \mathrm{E}$ in the Bhal region of Saurashtra, Bhavnagar District in the state of Gujarat (Fig. 1). The National Park (34.52 $\mathrm{km}^{2}$ ) and the surrounding area falling in $10 \mathrm{~km}$ radius from the park was considered as the study site for the present study.

Prior to India's independence (1947), the major part of the Bhal, including the area currently under the preserve, was under the princely state of Bhavnagar. Dharmakumarsinhji (1950) had carried out banding of lesser floricans during 1943 to 1950 and had ringed 489 floricans for seven years, of which 18 were recovered, 13 of these being from the Bhal region.

The study site is just above sea level and is only $18 \mathrm{~km}$ from the Gulf of Cambay (Ranjitsinh, 1982). Velavadar is $35 \mathrm{~km}$ north from the city of Bhavnagar and $22 \mathrm{~km}$ north-west of the town of Vallabhipur. 


\section{Climate}

The Bhal (literally meaning the forehead) is flat alluvial plain made up of a mosaic of croplands, saline wastelands, grazing grasslands, and marshes (Dharmakumarsinhji, 1978). Blackbuck National Park is the only grassland preserved in the Bhal area. Three seasons can be distinguished in Velavadar. Almost all the precipitation occurs during the monsoon, which begins during the latter half of June and continues to mid September. Sporadic showers may occur in October. The temperature ranges from 1 to $38^{\circ} \mathrm{C}$ in winter, which extends from November to February (Raychaudhri et al., 1963). Rare showers locally called "mavthu" occur during winter. Dew is a common feature during early morning throughout winter and sporadically in summer. Day temperatures normally range between 37 to $44^{\circ} \mathrm{C}$, but can be as high as $48^{\circ} \mathrm{C}$ in summer, which extends from March to mid June. Hot winds called "loo" sweep the hardbaked earth; dust storms, whirlwinds and dust devils are common. Mirages form as early as 2-3 hours after sunrise and continue throughout the day into late afternoon.

The Bhal region is prone to droughts and floods. Cyclones occasionally strike the coast of Saurashtra. During such times the Bhal becomes a large swamp. Blackbuck National Park is at a lower elevation than its surroundings and thus remains submerged for a longer duration. The average annual precipitation at Velavadar is about 468mm (Ranjitsinh, 1982). Eco-climate computed following Thornthwaite \& Mather (1955) for Velavadar by Ranjitsinh (1982) is semi-arid, fourth megathermal, and with no water surplus.

Plant growth is restricted to the monsoon and early winter. Crops are solely dependent on rains, as the ground water is saline. Wheat (Triticum sp.) is grown in winter in fields left fallow during the monsoon due to a good water retention capacity of Bhal soils. Cotton (Gossipyum sp.) Sorghum sp. and Kasumbi (Carghamus tinctorius) are the other major crops of the Bhal region.

\section{Habitat type}

Inside the Blackbuck National Park mainly four types of habitats are found, viz., grassland, shrubland, salineland and tidal mudflat. Grassland covers $60.9 \%$ area of the Park. There are 39 species of grass. Dichanthium annulatum, Sporobolous virginicus, S. coromandelianus, S. madernspatensis are the dominant grass species. The shrubland covers $15 \%$ of the area of which Prosopis chilensis is the dominant species. Saline land and tidal mudflat cover about $17 \%$ area of the park whereas $7 \%$ of the area is accounted for by roads and habitation (Jhala, 1991; Singh, 2001).

The surrounding area, outside of the national park is divisible into mainly, three types of habitats -- cropland, grassland amidst cropland, which is termed as grass patches, and revenue wasteland. Of these, cropland covers a major portion of the area in which farmers mainly cultivate sorghum and cotton during monsoon.

Grasslands amidst the croplands are tiny patches of grasses, which are not under the plough. Such patches also have Dicanthium sp. and Sporobolous sp. as the important grass species. Besides that, many approach roads to cropfields are not utilized during monsoon due to clayey and loamy soil of the Bhal area. Thick grass sprouts on such roads naturally attract the floricans.

The revenue wastelands are the area of open land and shrubland, which becomes sparse grassland during monsoon. These are the areas mainly utilized for livestock grazing during monsoon. The important vegetation in this area consists of Sporobolus sp., Chlaris virgata, Ischaemum rugosum, Iseilema anthepharoides, Suaeda nudiflora, Sesbania sp. etc. The invasion of Prosopis chilensis on revenue wasteland is very high, hence it is seldom utilized by Lesser Florican.

\section{Methods}

The study was conducted over about 150 days from 1 June to 31 October of 2001. Both the habitat types (grassland and cropland) in the study site were scanned thoroughly mainly from early morning to evening with a pair of binoculars. The floricans were recorded daily through direct sighting. As soon as the males develop breeding plumage, they establish territories and become localised (Sankaran, 1997a). The sightings of such territorial males were plotted on a map every fortnight to monitor the movement of male floricans.

An experienced field assistant, a local villager of Velavadar was employed to locate the floricans and the nests as well. As this species is threatened, intensive nest searches were not carried out, and the nest location was mainly by chance sighting. Location of nest and activities of nesting females was observed from a safe distance to avoid disturbance to the nesting female. The locations of nests, sightings of females, female with chicks etc. were plotted on the map of the study site.

The farmers and cattle herdsmen of surrounding villages were personally contacted. Posters of Lesser Florican were circulated among them to get more information about the bird. Anthropogenic pressures, like cattle grazing, movement of people in cropland for the removal of weeds, spraying pesticides or fertilizers, harvesting the crop etc. were recorded to establish the amount of disturbance such activities had on the Florican. 


\section{Results and Discussion}

\section{Nest and nesting sites disturbances}

Like all other species of bustards, the Lesser Florican is a ground nester. The nest in this family is a simple scrap in the ground without any nesting material added, and the behaviour associated with nest building is absent (Osborne et al., 1984).

A total of five nests were recorded during the study period. All the five nests were outside the protected area, i.e. in the surrounding area on the periphery of the National Park. All the five nests were within $150 \mathrm{~m}$ from the water hole. At the location of all the nests the grass height was 30 to $50 \mathrm{~cm}$.

Two nests were in revenue wasteland with sparse grassland mixed with shrubs like, Sesbania grandifolia, Suaeda nudiflora among others. These nests were well away from the male's territory but they were not far from the water hole. One nest was recorded from the revenue land close to village Mevasa. The nest was recorded on 1 August. It was on high elevation hence was not inundated by heavy rain. The other nest was recorded from the revenue land just outside the southern boundary of the National Park, which is near Velavadar Village. The nest was recorded on 7 August at a low elevation, hence was inundated due to heavy rains.

Three nests were in the grass patches amidst the cropland. Of them one was from Velavadar Village, recorded on 20 July, which was the earliest nest recorded during the present study. Two nests were recorded on 30 July and 7 August from the grass patches of Mithapur Village. The nests in the grass patches, were within $150 \mathrm{~m}$ of the male's territory (Table 1 ). It was also observed that the locations of the nests in the grass patches were near the edge of the patch, close to hedge of cropland (at $1-2 \mathrm{~m}$ distance). The area was occasionally used by the farmers when carrying their plough, bullocks, tractors etc. to their farms, and unknowingly trampled the nests.

To reproduce successfully, a bird should nest when environmental conditions are most favourable (Earle, 1981). Breeding success is determined by the available resources such as the presence of adequate cover for nesting and hiding the young, and the availability of adequate food. Perennial grasslands of Blackbuck National Park and surrounding area offers such favourable resources and attracts large number of Lesser Floricans in the breeding season. However, their breeding success, particularly hatching of eggs, was found to be alarmingly low due to anthropogenic disturbances.

\section{Clutch size and hatching success}

The eggs were almost spherical and dark olive green in colour. The males did not played any role in the process of incubation. The incubation period could not be ascertained, because the field condition was not favourable for carrying out regular observation on the located nests but according to Dharmakumarsinhji (1950) and Sankaran (1997b) the incubation period is 21 days. Table 1 reveals that, of the five nests recorded during the study, two had five eggs and three had four. Out of five nests, three were totally destroyed. Two nests were recorded near Velavadar, of which, one was in grass patch, destroyed by some predator, probably by crows it was assumed from the condition of the eggshell. The other nest was inundated due to heavy rain in the beginning of August. A nest in revenue land near Mevasa village was slightly on elevation, hence it was not inundated, but the nest could not be approached due to inundation of the surrounding area. A farmer reported seeing a

Table 1. Nesting data of Lesser Florican during the study period

\begin{tabular}{|c|c|c|c|c|c|c|}
\hline $\begin{array}{l}\text { Date of } \\
\text { record }\end{array}$ & $\begin{array}{l}\text { No. of } \\
\text { eggs }\end{array}$ & $\begin{array}{l}\text { Habitat } \\
\text { type }\end{array}$ & $\begin{array}{l}\text { Aprox. dist. }(\mathrm{m}) \\
\text { from male } \\
\text { territory }\end{array}$ & $\begin{array}{l}\text { Aprox. dist. (m) } \\
\text { from water } \\
\text { hole }\end{array}$ & $\begin{array}{l}\text { In area of } \\
\text { village }\end{array}$ & Remarks \\
\hline 20.vii.01 & 4 & $\begin{array}{l}\text { Grass } \\
\text { Patch }\end{array}$ & 100 & 150 & Velavadar & $\begin{array}{l}\text { All the } 4 \text { eggs were destroyed, } \\
\text { probably by crow. }\end{array}$ \\
\hline 30.vii.01 & 4 & $\begin{array}{l}\text { Grass } \\
\text { Patch }\end{array}$ & 150 & 100 & Mithapur & $\begin{array}{l}\text { All the } 4 \text { eggs were trampled by cattle } \\
\text { after } 7 \text { days, the hen abandoned the site }\end{array}$ \\
\hline 01.viii.01 & 5 & $\begin{array}{l}\text { Revenue } \\
\text { Land }\end{array}$ & $>300$ & 100 & Mevasa & $\begin{array}{l}\text { On 18-8-01 a farmer reported, } \\
\text { all the eggs were hatched }\end{array}$ \\
\hline 05.viii.01 & 5 & $\begin{array}{l}\text { Grass } \\
\text { Patch }\end{array}$ & 50 & 125 & Mithapur & $\begin{array}{l}\text { Two eggs were trampled on 8-8-01 while } \\
\text { ploughing, hen did not abondoned the nest, } \\
\text { three eggs were hatched on 10-8-01. }\end{array}$ \\
\hline 07.viii.01 & 4 & $\begin{array}{l}\text { Revenue } \\
\text { Land }\end{array}$ & $>400$ & 150 & Velavadar & The nest was inundated due to heavy rain \\
\hline
\end{tabular}


Table 2. Fortnightly sightings of male floricans in the study site.

\begin{tabular}{lll}
\hline Date & Within BNP & Outside BNP \\
\hline 06.vi.01 & 1 & 0 \\
20.vi.01 & 20 & 0 \\
04.vii.01 & 25 & 0 \\
18.vii.01 & 38 & 0 \\
01.viii.01 & 25 & 7 \\
15.viii.01 & 14 & 9 \\
29.viii.01 & 9 & 20 \\
12.ix.01 & 13 & 23 \\
26.ix.01 & 10 & 14 \\
03.x.01 & 6 & 4 \\
17.x.01 & 3 & 2 \\
31.x.01 & 0 & 0 \\
\hline
\end{tabular}

hen with five chicks in the nearby area where that nest was located. Of two nests recorded near Mithapur, in one case, cattle trampled all the four eggs, so the female abandoned it but in another nest only two eggs were trampled. The florican did not abandon that nest. After two days a farmer reported that all the remaining three eggs hatched and the hen had left the nest site along with chicks.

Thus, out of five nests located, eggs were hatched only in two nests. Both the nests had five eggs each. Of them, all the five eggs were hatched in one nest whereas, in the other, only three eggs hatched. Thus out of 22 eggs from five nests only eight hatched. The hatching success or breeding success cannot be calculated from such a small sample of a short-term study.

In normal southwest monsoon conditions the rains peak in the last two weeks of July. Until early August there are frequent spells of rains when it can rain for two or three days continuously. Thus the risk of inundation of the nest is high until mid August (Sankaran, 1997b). Several studies have shown that inundation or bad weather comprises a significant proportion of factors that destroy eggs and nests (Shipley, 1984; Warriner et al., 1986).

In the month of October two sightings of female florican with chicks were recorded. On 11 October and on 23 October, a hen with two chicks were sighted while crossing the road in the National Park. The chicks sighted on 11 October were bigger
Table 3. Date-wise sightings of female floricans in the study site

\begin{tabular}{llll}
\hline Date & WP & OP & Remarks \\
\hline 06.vi.01 & 1 & 0 & \\
11.vi.01 & 1 & 0 & \\
13.vi.01 & 1 & 0 & \\
22.vi.01 & 1 & 0 & \\
24.vi.01 & 1 & 0 & \\
08.viii.01 & 1 & 0 & \\
20.viii.01 & 0 & 1 & on nest, in grass patch, Velavadar village \\
30.viii.01 & 0 & 1 & on nest, revenue land, Mevasa village \\
01.viii.01 & 0 & 1 & on nest, revenue land, Mithapur village \\
04.viii.01 & 1 & 0 & \\
05.viii.01 & 0 & 1 & on nest, grass patch, Mithapur village \\
07.viii.01 & 0 & 1 & on nest, revenue land, Velavadar village \\
18.viii.01 & 1 & 0 & \\
17.ix.01 & 0 & 1 & in sorghum field, Velavadar village \\
11.x.01 & 1 & 0 & with two chicks, in the National Park \\
23.x.01 & 1 & 0 & with two chicks, in the National Park \\
& & &
\end{tabular}

in size compared to the chicks sighted on 23 October. Hence it was assumed that both females were different and they had nested in the National Park. No nests were located in the National Park due to the tall and thick grass in the grassland of the Park. Thus, of the 12 sightings of chicks recorded, four were within the Park and eight were outside the Park.

Since the incubation period of eggs is only 21 days and the freshly hatched chicks are precocial, the nest requires protection only during this period (25-30 days). This would certainly

Table 4. Number of displaying males in various habitat types in the site at different time during the study period.

\begin{tabular}{lllll}
\hline & Within NP & & \multicolumn{2}{c}{ Outside NP } \\
$\begin{array}{l}\text { Thick } \\
\text { grassland }\end{array}$ & $\begin{array}{l}\text { Sparse } \\
\text { grassland }\end{array}$ & $\begin{array}{l}\text { Grass } \\
\text { patches }\end{array}$ & Cropland & $\begin{array}{l}\text { Revenue } \\
\text { land }\end{array}$ \\
\hline 32 & 6 & 15 & 6 & 2 \\
\hline
\end{tabular}

NP - National Park 
enhance the hatching success of eggs and eventually the survival of chicks.

\section{Behaviour of female on nest}

While on the nest, female Lesser Floricans did not flush unless almost trampled upon. They preferred to avoid detection by sitting tight on the eggs. Thus even a known nest with incubating female is unnoticeable, from as close as $3 \mathrm{~m}$ or even less. The tendency of females not to flush or move away at the sound of approaching danger enables the poachers of the area to trap the incubating hen simply by throwing a net (Sankaran, 1997b). The evidence of stray sightings suggests that the females with chicks stay on in the grassland until the end of November (Shivbhadrasinhji, pers. comm.).

\section{Nesting period}

All the nests were recorded between 20 July and 7 August. It seems that nesting began in the third week of July. Sightings of a female with chicks were recorded in the month of October (Table 2). It was also observed that, when females were sighted with chicks, the age of chicks was about 15 to 30 days. The sight records show that nesting activities continued until the end of September.

\section{Sight locations of male and female floricans}

The arrival of Lesser Floricans commenced from 6 June. A male and a female were sighted on the same day. After a fortnight the population of males reached 20 and at the end of a month i.e. on 4 July the population reached 25 . A maximum number of 38 male floricans were sighted in the third and fourth weeks of July (Table 2). Initially the floricans were sighted in the grassland of the Park. From the fourth week onwards the male floricans were sighted outside the National Park area. Table 2 shows a maximum of 23 males recorded outside the National Park. The males were located in the area of four villages on the periphery of the National Park. Nine males were recorded near Mithapur, 12 near Velavadar and two near Mevasa. One male was recorded near Anandpur between 15 and 29 August 2001; in all 23 males were recorded outside the Park during the study period.

The first sighting of a female florican during the study was on 6 June. Totally 10 females were sighted in the National Park area and six were sighted outside the Park (Table 3 ). Of the six females sighted outside the Park, five were on the nest and one female was sighted feeding in a sorghum field near Velavadar Village. The female florican is extremely shy and therefore it is difficult to sight. Females were sighted only while crossing roads, in flight, or on the nest. Three females were sighted near Velavadar Village, two were near Mithapur and one near Mevasa. A sighting of female was also recorded on 23 October crossing the road with two chicks. The higher number of sightings of females within the National Park area in the beginning of the breeding season suggests that females initially utilize the grasslands of National Park and possibly after mating they disperse towards grass patches amidst the crop land outside the National Park area.

\section{Habitat preference}

Ali \& Ripley (1983) described their habitat as "tall grassland with scattered bushes and standing crop of cotton and millets". The primary habitat requirement for breeding is grassland where sufficient grass cover is available. The Lesser Florican does not prefer marshes, wetland or barren land (Sankaran, 1994). Undisturbed vegetation cover appears to be of the greatest importance in habitat selection during the breeding season of the Lesser Florican (Sankaran, 1997a).

Table 2 shows, that the Lesser Florican had solely utilized the grasslands of National Park up to the end of the third week of July. The thick patches of important grass species like Sporobolus and Dicanthium provide ideal habitat for a safe shelter, as well as for the courtship display. Due to normal monsoon, the grass height crossed $60 \mathrm{~cm}$, which resulted in early dispersal of male Lesser Florican from the National Park, as tall grass is not preferred by the floricans (Sankaran, 1997a). The highest number of males recorded in the National Park was 38 of which 32 were in the dense grassland in the northern part of the National Park and six were in the southern and southeastern parts of the National Park in sparse grassland. Similarly, the highest number of displaying males recorded outside the National Park was 23 by the second week of September. Of them 15 were in the grass patches amidst cropland, six were in cropland (Sorghum field) and only two were in the sparse grass in the revenue land (Table 4). In another study it was observed that male floricans in the National Park area utilised fire line area with short grass for display and the tall grasses on margins of fire line to hide from any danger (Srivastav \& Rana, 1998). A similar phenomenon was observed at Sailana Kharmor Sanctuary, Madhya Pradesh (Sankaran, 1997a). The optimal range of grass height for Lesser Florican was difficult to determine because the period of lowest grass height coincided with grazing. However, very tall grass was not preferred by floricans. The male birds, which had territories in grasslands, shifted to crop field or patch and mud road within the grassland when the grass grew tall (Sankaran, 1997b).

Only five nests were located during the study period -- three were from the grass patches amidst the cropland and two were from sparse grassland in the revenue wasteland (Table 1). Though $60 \%$ of the park is protected grassland, not a single nest was recorded from within the National Park. This could be due to an increased population of Nilgai (Boselaphus tragocamelus), Wild Boar (Sus scrofa) and Jackals (Canis aureus) in the National Park. Similarly, the revenue wasteland with sparse grassland was found to be highly disturbed by cattle grazing. Hence the grass patches amidst the cropland 
were preferred for nesting. According to Sankaran (1997b) the choice of habitat is determined more by disturbance factors and to a lesser extent, rainfall regimes.

\section{Community involvement}

The main profession of the people in the surrounding area is agriculture and dairy farming. During the monsoon the herdsmen graze their cattle in the surrounding area of the National Park. The farmers and herdsmen are reported to destroy the nests of Lesser Floricans unknowingly. About 100 farmers and cattle herdsmen were contacted and spoken to to convince them to try and prevent disturbance to the nesting floricans. A poster with a coloured picture and information regarding the importance of grassland for survival of the species in Gujarati language was circulated to all of them. The information about the present status of the Lesser Florican in India was given. The behaviour of incubating and brooding female was explained to the farmers and herdsmen and they were told that the only solution to conserve the species is prevention of disturbance during the nesting period, i.e. from July to September.

The people accepted the fact of population decline of Lesser Florican in Bhal region and supported the requirement of its conservation. The area of grassland at the time of independence was 10 times more than that presently under Blackbuck National Park. They showed their sympathy towards the species and many of them promised to protect the bird in future which itself is a long lasting achievement for the conservation of Lesser Florican.

\section{Limitations of the study}

The major limitation of the study was field condition. Heavy rain during July and August inundated a major part of the study site. It was very difficult to walk through such areas to locate nests and carry out regular observation on the located nests. It would have been possible to survey the entire swampy area on camel back, but the limitations of budget did not permit to hire a camel for three months.

\section{Threats}

Based on the field work carried out during the present study and from the view of a few experts it is found that the Lesser Floricans face the following threats in the Bhal area.

\section{Habitat loss}

The grassland of the National Park area is well protected and well managed but a gradual encroachment is observed on the grass patches amidst the cropland outside the National Park by the farmers of surrounding area. Prosopis chilensis is encroaching the sparse grassland in the revenue land area. Increasing saltpans in Bhal region greatly increase the salinity, which results in gradual loss of once rich grassland.

\section{Livestock grazing}

The estimated population of livestock in the surrounding villages of Blackbuck National Park is more than 10,000 (Jhala, 1991). During monsoon and early winter the livestock remain in the Bhal grazing in surrounding areas of the Park. The nests outside the National Park are prone to trampling by cattle. The present study also indicated nests trampled by cattle.

\section{Agricultural practices}

Insects form a large part of the diet of the Lesser Florican. In Bhal region, farmers mainly cultivate sorghum and cotton. Large amounts of pesticides are regularly sprayed on the cotton plants. The birds use crop fields extensively during the breeding season. The effect of indiscriminate use of pesticides in agriculture on the Lesser Florican is unknown (Sankaran, 1994).

Continuous movement of farmers in cropland for ploughing, weeding etc. sometimes damage the nests or disturb the brooding female (Rana, pers. comm.).

\section{Hunting}

Hunting of Lesser Florican in Bhal region is unknown. According to local villagers, people of certain community (Vaghari and Koli) sometimes collect eggs, kill a brooding female and capture the displaying males by using snares outside the National Park.

\section{Other}

An important threat is increasing population of Nilgai in the National Park. The population of Nilgai (449), Wild Boar (154) and Jackal (34) has increased in the National Park during the last 3-4 years (Singh 2001). The increased population of the Nilgai may increase the chances of trampling of eggs and chicks; the increased population of Wild Boar and Jackal also increases the risk of predation of eggs and chicks of Lesser Floricans.

\section{Recommendations}

The Lesser Florican is now under an increased threat of extinction (Sankaran, 1994). The population has fallen well bellow the levels from which it can not recover. On the basis of present study following recommendations are suggested.

\section{Involvement of the community}

It is very difficult to conserve any species without the involvement of local people, particularly in the area which is outside the protected area. These areas are, nevertheless, very valuable for florican conservation. With the help of NGOs, local people should be made aware about the present status and conservation of the bird.

Two to three Florican chowkidars (watchmen) should be appointed on daily wage basis from the surrounding villages. The duty of florican chowkidar should be to protect the birds as well as their nests from cattle and poachers. The chowkidars 
are required for only three months i.e. from July to September. Thus the local villagers would get employment and in return the floricans get protection.

\section{Habitat improvement programme}

According to the National Park authorityies, 2200ha of the forestl and has been handed over to the Blackbuck National Park (for administration), which was earlier in possession of the Normal Division of Forest Department, Bhavnagar District. The major part of this land is covered with Prosopis chilensis. The land can be gradually developed as fodder producing grassland. The increasing demand for fodder requires an immediate change in the existing land use pattern on government land.

The grassland development may be implemented under the head of ecodevelopment programme. The practice of cattle camps must be continued and fodder supplied to the camps from the newly created grassland. The existing network of cattle camps must be expanded and made mandatory and permanent feature for rural development.

\section{Florican watch}

The results and limitations of the present study suggest a longterm study on breeding activity of the Lesser Florican in the Bhal region which would provide facts about population growth and solutions for conservation.

The Florican Watch Programme initiated by Sankaran (1994), should be resumed. The Bhal area in Saurashtra and Banni and Nalia area of Kutch are the strongholds of Lesser Floricans in western India (Sankaran, 1996). These areas should be intensively surveyed for five to six years and involve communities by providing information regarding the present status of Lesser Floricans.

\section{Acknowledgement}

The field study was made possible by the funding provided by Wildlife Trust of India, New Delhi. I thank Mr. M.K.S. Pasha, Programme Officer, Wild Aid, Wildlife Trust of India, for his support and continuous help. I am thankful to the Chief Conservator of Forests, Wildlife, Government of Gujarat for giving permission for the study. I also thank Mr. B.J. Pathak, Conservator of Forests, Wildlife Circle, Junagadh, Mr. L.N. Jadeja, ACF, and entire staff of the Blackbuck National Park, for their kind cooperation and hospitality during the study period. I am greatly thankful to Mr. Bharat Jethva, Wildlife Institute of India and Mr. V.J. Rana, ACF Sasan, Dr. Raju Vyas and Mr. Pranav Trivedi for their continuous encouragement and valuable suggestions during the entire study. The field assistant Mr. Allarakh needs to be acknowledged for his dedication to his work.

\section{References}

Ali, S. and S.D. Ripley (1983). The Handbook of the Birds of India and Pakisatan. Compact Edition. Oxford University Press, New Delhi.

Collar, N.J. and P. Andrew (1994). Birds to Watch. The ICBP world
Checklist of Threatened Birds. International Council for Bird Preservation, Cambridge.

del Hoyo, J., A. Elliot and J. Sargatal (1996) (editors). Handbook of the Birds of the World. Vol. 3. Hoatzins to Auks. Lynx Edicions. Barcelona. Dharamkumarsinhji, R.S. (1950). The Lesser Florican (Sypheotides indica Miller): its courtship display, behaviour and habits. Journal of the Bombay Natural History Society 49: 201-216.

Dharmakumarsinhji, R.S. (1978). Velavadar National Park, Gujarat India. Tigerpaper 5(1): 6-8.

Earle, R.A. (1981). Factors governing avian breeding in Acacia Savanna, Pietermaritzburg. Part 1: Extrinsic factors. Ostrich 52: 65-73.

Grimmett, R.C., Inskipp and T. Inskipp (1998). Birds of the Indian subcontinent, Oxford University Press, Delhi, pp 456-459.

Jhala, Y.V. (1991). Habitat and population dynamics of wolves and blackbuck in Velavadar National Park, Gujarat, India. Ph.D. Thesis, pp48. Virginia Polytechnic Institute and State University, Blacksburg, Virginia. Osborne, P., N. Collar and P.D. Goriup (1984). Bustards. Dubai Wildlife Research Centre. Dubai, U.A.E.

Ranjitsinh, M.K. (1982). Ecology and behaviour of the Indian Blackbuck. Ph.D.Thesis. Saurashtra University, Gujarat, India, 290pp.

Raychaudhari, S.P., R.R. Agarwal, N.R.D. Biswas, S.P. Gupta, and P.K.Thomas (1963). Soils of India. Indian Council of Agricultural Research, New Delhi, 496pp.

Sankaran, R. (1991). Some aspects of the breeding behaviour of the Lesser Florican Sypheotides indica (J.F. Miller) and the Bengal Florican Eupodotis bengalensis (Gmelin). Ph.D. Thesis, University of Bombay. Sankaran, R. (1994). Status of the Lesser Florican in 1994. Salim Ali Centre for Ornithology and Natural History, Coimbatore. Unpublished Report.

Sankaran, R. (1995). A fresh initiative to conserve the Lesser Florican. Oriental Bird Club Bulletin 22: 42-44.

Sankaran, R. (1996). Background paper for the workshop on conservation of the Lesser Florican. Salim Ali Centre for Ornithology and Natural History, Coimbatore. Unpublished Report, Kota.

Sankaran, R. (1997a). Habitat use by the Lesser Florican. Journal of the Bombay Natural History Society 94(1): 40-47.

Sankaran, R. (1997b). Nesting of Lesser Florican during southwest monsoon. Journal of the Bombay Natural History Society 94(2): 401403.

Sankaran, R. (2000). The status of the Lesser Florican Sypheotides indica in 1999. Salim Ali Centre for Ornithology \& Natural History and Bombay Natural History Society. Unpublished Report.

Sankaran, R., A.R. Rahmani and U. Ganguli-Lachungpa (1992). The distribution and status of the Lesser Florican Sypheotides indica (J.F. Miller) in the Indian subcontinent. Journal of the Bombay Natural History Society 89: 156-179.

Srivastav, A.K. and V. Rana (1998): Velavadar National Park: A paradise for Lesser Florican. Tigerpaper 25(3): 1-4.

Shipley, F.S. (1984). The 4-egg clutch limit in the Charadrii: an experiment with American Avocets. South Western Naturalist 29: 143-147.

Singh, H.S. (2001). Natural heritage of Gujarat (Forests and Wildlife), GEER Foundation, Gandhinagar. pp. 87-89

Thornthwait, C.W. and J.R. Mather (1955). The water balance. Publication in climatology, Drexel Institute of Technology, New Jersey 8: 1-104.

Warriner, J.S., J.C. Warriner., G.W. Page and L.E. Stenzel (1986). Mating success and reproductive success of a small population of polygamous Snowy Plovers. Wilson Bulletin 98: 15-37. 